\title{
ENDOSCOPIC CHANGES RELATED TO GASTROESOPHAGEAL REFLUX DISEASE: COMPARATIVE STUDY AMONG BARIATRIC SURGERY PATIENTS
}

Alterações endoscópicas relacionadas à doença do refluxo gastroesofágico: estudo comparativo entre obesos submetidos à cirurgia bariátrica*

\author{
Marco Aurelio SANTO, Sylvia Regina QUINTANILHA*, Cesar Augusto MIETTI*,
} Flavio Masato KAWAMOTO, Allan Garms MARSON, Roberto de CLEVA

From the Unidade de Cirurgia Bariátrica e Metabólica, Disciplina de Cirurgia do Aparelho Digestivo, Departamento de Gastroenterologia, Hospital das Clínicas da Faculdade de Medicina da Universidade de São Paulo (Bariatric and Metabolic Surgery Unit, Digestive Surgery Discipline, Department of Gastroenterology, Hospital das Clinicas, Medical School, University of São Paulo), São Paulo, SP, Brazil

* This paper was awarded with First Prize among the presented at the VIII Brazilian Digestive Week 2013

\section{HEADINGS - Morbid obesity.}

Gastroesophageal reflux. Esophagitis.

Hiatal hernia. Bariatric surgery.
ABSTRACT - Background: Obesity is correlated with several comorbidities, including gastroesophageal reflux disease. Its main complications are detectable by endoscopy: erosive esophagitis and Barrett's esophagus. Aim: To correlate erosive esophagitis and hiatal hernia with the degree of body mass index (BMI). Method: Was performed a retrospective analysis of 717 preoperative endoscopic reports of bariatric patients. Fiftysix (8\%) presented hiatal hernia, being 44 small, nine medium and five large. Esophagitis was classified by Los Angeles classification. Results: There was no correlation between the presence and dimension of hiatal hernia with BMI. One hundred thirty-four (18.7\%) patients presented erosive esophagitis. Among them, 104 (14.5\%) had esophagitis grade $A ; 25(3.5 \%)$ grade $B$; and five $(0.7 \%)$ grade $C$. When considering only the patients with erosive esophagitis, $77.6 \%$ had esophagitis grade $A, 18.7 \%$ grade $B$ and $3.7 \%$ grade $C$. Were identified only two patients with Barrett's esophagus $(0,28 \%)$. Conclusion: There was a positive correlation between the degree of esophagitis with increasing BMI.

\section{Correspondence: \\ Marco Aurelio Santo \\ E-mail: santomarco@uol.com.br \\ Financial source: none \\ Conflicts of interest: none}

Received for publication: 26/02/2015 Accepted for publication: 02/06/2015

DESCRTORES: Obesidade mórbida. Refluxo gastroesofágico. Esofagite. Hérnia de hiato. Cirurgia bariátrica.
RESUMO - Racional: A obesidade está correlacionada com diversas comorbidades, dentre elas a doença do refluxo gastroesofágico. Ela tem como um de seus principais desencadeantes a hérnia do hiato, e como suas principais complicações a esofagite erosiva e o esôfago de Barrett. Objetivo: Correlacionar o grau do índice de massa corporal (IMC) com a presença e tamanho da hérnia hiatal, e com a presença e gravidade da esofagite erosiva e esôfago de Barrett. Método: Foi realizada análise retrospectiva de laudos endoscópicos pré-operatórios de 717 pacientes submetidos à cirurgia bariátrica. A hérnia de hiato esteve presente em 56 pacientes (8\%), sendo que delas 44 eram pequenas, nove médias e cinco grandes. O grau da esofagite obedeceu o preconizado pela Classificação de Los Angeles. Resultados: Não houve correlação entre a presença ou tamanho da herniação hiatal com o IMC. Dos pacientes avaliados, $134(18,7 \%)$ apresentavam esofagite erosiva. Dentre elas 104 (14,5\%) eram grau $A ; 25(3,5 \%)$ grau $B$ e cinco $(0,7 \%)$ grau $C$. Considerando-se apenas os portadores de esofagite erosiva, $77,6 \%$ eram grau $A ; 18,7 \%$ grau $B ;$ e 3,7\% grau $C$. Foram identificados apenas dois casos de esôfago de Barrett ( $0,28 \%$ da amostra total). Conclusão: Observou-se correlação positiva entre o grau de esofagite com o aumento do IMC. he World Health Organization defines obesity as fat accumulation that determines health risk. Body mass index (BMI) was established as a worldwide standard for assessing the severity of obesity, which is calculated by dividing the patient's weight in kilograms by the square of their height in meters. Presence of obesity is considered when BMI $>30 \mathrm{~kg} / \mathrm{m}^{2}$. Patients with $\mathrm{IMC} \geq 35$ and $<40 \mathrm{~kg} / \mathrm{m}^{2}$ are classified with class II obesity; with BMI $>40 \mathrm{~kg} / \mathrm{m}^{2}$ grade III or serious; and BMI $>50 \mathrm{~kg} /$ $\mathrm{m}^{2}$ super-obese.

In the United States it is estimated that one third of the adult population is in the obesity range and $4.8 \%$ of the population over 20 years present morbid obesity ${ }^{1}$. In São Paulo the percentage of obese adults is approximately $12 \%$, with higher prevalence in young adult population. Obesity is accompanied by associated systemic diseases such as hypertension, diabetes mellitus, insulin resistance, dyslipidemia and diseases of the digestive tract such as gastroesophageal reflux disease (GERD), cholelithiasis and nonalcoholic fatty liver disease.

Symptomatic GERD is frequent in the population of obese patients, with prevalence ranging from $30-60 \% 5$. Patients with obesity have a high intra-abdominal pressure and consequent increase in gastroesophageal pressure gradient, increasing both the esophageal gastric juice exposure ${ }^{6}$ juice, and the risk of hiatal hernia ${ }^{8}$. Apart from GERD and erosive esophagitis, recent studies show increased incidence of esophageal adenocarcinoma in morbid obese ${ }^{11,12}$. However, there is no description in the literature about the relationship of the occurrence of these changes with the strongest degrees of severe obesity. 
The intense and prolonged exposure of the esophageal epithelium to gastric juice causes chronic esophagitis and in the damaged can be observed replacing of the squamous epithelium columnar cells by intestinal metaplasia, condition called Barrett's esophagus. This metaplastic process can progress to dysplastic process and subsequent formation of adenocarcinoma ${ }^{25}$ The traditional definition of Barrett's esophagus required the metaplastic epithelium be over the extent to $3 \mathrm{~cm}$ from the esophagogastric junction. However, more recently it was observed that lesions with involvement of lower extension of the distal esophagus mucosa, and even restricted to the esophagogastric junction, are related to gastroesophageal reflux and have malignant potential, and therefore are also classified as Barrett's esophagus ${ }^{3}$.

The aim of this study was to evaluate the endoscopic GERD-related changes in the preoperative of bariatric surgery, comparing the degree of BMI and the prevalence of hiatal hernia, erosive esophagitis and Barrett's esophagus.

\section{METHODS}

Were studied 717 patients undergoing bariatric surgery at the Bariatric and Metabolic Surgery Unit of the Hospital das Clinicas, Faculty of Medicine, University of São Paulo, São Paulo, SP, Brazil, from 2007 to 2012.

It was a retrospective study with analysis of preoperative endoscopic reports and evaluated the changes related to GERD (hiatal hernia, reflux esophagitis and Barrett's esophagus) as classified below.

Hiatus hernia was classified according to the size of the herniated gastric chamber: 1) small, 1 to $3 \mathrm{~cm}$; 2) medium, between $3 \mathrm{~cm}$ and $5 \mathrm{~cm}$; and 3) large, more than $5 \mathrm{~cm}$.

Reflux esophagitis was classified according to the Los Angeles classification. Barrett's esophagus was classified according to their length (Figure 1 ).

\begin{tabular}{|c|c|}
\hline$-T_{R} /$, & $\begin{array}{l}\text { Não há evidência endoscópica de alteração epitelial do esôfago distal, porém biópsias } \\
\text { da transiçẫo esofagogástrica evidenciam a presença de metaplasia intestinal }\end{array}$ \\
\hline CURTO & Alteração endoscópica do epitélio esofágico com extensão menor que $3 \mathrm{~cm}$ \\
\hline LONGO & Alteração endoscópica do epitélio esofágico com extensão maior ou igual a $3 \mathrm{~cm}$ \\
\hline
\end{tabular}

FIGURE 1 - Barrett's esophagus classified in accordance to its extension

Patients were divided into three groups according to BMI: group I, BMI $\geq 35$ and $<40 \mathrm{~kg} / \mathrm{m}^{2} ;$ group II, IMC $\geq 40$ and $<50$ $\mathrm{kg} / \mathrm{m}^{2}$; and group III, IMC $\geq 50$.

\section{Statistical analysis}

It was performed using the SPSS 12 (SPSS, Chicago, Illinois). The data of continuous variables were expressed as mean \pm standard deviation and categorical variables as percentages. The differences between the groups in continuous variables were determined using the Student $t$ test and the categorical variables using Chi-square, and the relationship between severity of esophagitis and BMI was given by Gamma test, with the level of defined statistical significance at $p<0.05$.

RESULTS

\section{Hiatal hernia}

The analysis showed the presence of endoscopic hiatal hernia in $8 \%$ of patients $(n=58)$ whereas in 44 it was small, nine medium and five large (Table 1 ).

No correlation was observed between the presence of hernia and BMI $(p=0.612)$. There was no positive correlation between the presence or size of hiatal hernia between superobese (BMI > 50), patients with a BMI between 40 and 50 and patients with BMI between 35 and 40 (obesity GII).
TABLE 1 - Distribution in number and percentage of patients with hiatal hernia by the size

\begin{tabular}{|c|c|c|c|}
\hline Herniation & $\mathbf{n}$ & \% sample & Hernia \\
\hline Small & 44 & $6 \%$ & $76 \%$ \\
\hline Medium & 9 & $1.3 \%$ & $15 \%$ \\
\hline Large & 5 & $0.7 \%$ & $9 \%$ \\
\hline TOTAL & 58 & $8 \%$ & $100 \%$ \\
\hline
\end{tabular}

\section{Reflux esophagitis}

It was observed the presence of reflux esophagitis in 134 patients, corresponding to $18.7 \%$ of the sample $(n=717)$. Compared to the total sample $14.5 \%(n=104)$ had erosive esophagitis grade $A ; 3.5 \%(n=25)$ grade $B$; and $0.7 \%(n=5)$ grade $C$. No patient had esophagitis grade $D$. Considering only patients with esophagitis $(n=134), 77.6 \%$ had esophagitis grade A, $18.7 \%$ grade $B$ and 3 7\% grade C (Table 2 ).

TABLE 2 - Distribution in number and percentage of patients with reflux esophagitis by Los Angeles classification

\begin{tabular}{|c|c|c|c|}
\hline Classification & $\mathbf{n}$ & \% sample & DRGE \\
\hline Grade A & 104 & $14.5 \%$ & $77.6 \%$ \\
\hline Grade B & 25 & $3.5 \%$ & $18.7 \%$ \\
\hline Grade C & 5 & $0.7 \%$ & $3.7 \%$ \\
\hline Grade D & 0 & $0 \%$ & $0 \%$ \\
\hline TOTAL & 134 & $18,7 \%$ & $100 \%$ \\
\hline
\end{tabular}

Classifying patients with esophagitis according to BMI, it was observed that nine had BMI between 35 and 40, 79 between 40 and 50 , and 46 were superobese. (Table 3)

TABLE 3 - Distribution of patients by BMI and the presence/ severity of reflux esophagitis

\begin{tabular}{|c|c|c|c|c|c|}
\hline BMI & $\mathrm{n}$ & Esophagitis & Grade A & Grade B & Grade C \\
\hline$\geq 35$ e $<40$ & 81 & $9(11.1 \%)$ & $6(7.4 \%)$ & $3(3.7 \%)$ & 0 \\
\hline 240 and $<50$ & 435 & $79(18.1 \%)$ & $61(14.0 \%)$ & $14(3.2 \%)$ & $4(1 \%)$ \\
\hline$\geq 50$ & 201 & $46(22.8 \%)$ & $37(18.4 \%)$ & $8(3.9 \%)$ & $1(0.5 \%)$ \\
\hline TOTAL & 717 & 134 & 104 & 25 & 5 \\
\hline
\end{tabular}

There was a positive correlation between the presence of erosive esophagitis and BMI. Superobese patients had a higher prevalence of esophagitis than obese with BMI between 35 and 40 (obesity GII) $(p=0.03)$. Comparing superobese and patients with BMI between 40 and 50 was not identified any relationship $(p=0.165)$, also in patients with BMI between 35 and 40 (obesity GII) and BMI between 40 and 50 ( $p=0.148$ ).

\section{Barrett's esophagus}

It was observed only two cases of Barrett's esophagus in 717 endoscopies, showing prevalence of $0.28 \%$ in the sample.

\section{DISCUSSION}

Currently, the prevalence of GERD has increased, affecting between $8-26 \%$ of the occidental population ${ }^{26}$. Associated with the increase, was observed increase in related complications, including Barrett's and adenocarcinoma of the esophagus 4 . Reasons for both increase in GERD, as its complications, are not yet completely understood.

It should be noted that the increased prevalence of GERD accompanies the worldwide epidemic obesity. The effect of weight gain on the GERD is important, it is estimated that the increase of 3.5 points in BMI increases by approximately three times the risk of developing symptoms of reflux ${ }^{21}$.

Obesity has also been associated with increased intraabdominal pressure ${ }^{2}$, decrease in gastric emptying ${ }^{18}$ and in lower esophageal sphincter pressure, and increase of transient sphincter relaxation ${ }^{23}$, changes that together determine increased 
esophageal exposure to hydrochloric acid.

Some papers demonstrated the association of GERD with the prevalence of obesity, especially the ones of Nilsson ${ }^{22}$, Murray ${ }^{20}$ and Lagergren ${ }^{17}$. It should be noted that no studies have observed negative association between GERD and obesity.

In this paper, $18.7 \%$ of obese patients had esophagitis, prevalence greater than that observed in general population ${ }^{14}$, suggesting a positive association between them, although the prevalence is similar to that observed in occidentals ${ }^{26}$. There was a positive correlation between the presence of erosive esophagitis and BMI, particularly when compared superobese patients and patients with BMI between 35 and 40 (obesity GII) $(p=0.03)$. Comparing superobese and patients with BMI between 40 and 50 was not identified this relationship $(p=0.165)$, as far as between patients with BMI between 35 and 40 (obesity GII) and BMI between 40 and $50(p=0.148)$. Thus, the presence of more severe obesity is considered as a risk factor for esofagitis ${ }^{27}$.

Both overweight and obesity meet numerous criteria for association with GERD, including hiatal hernia. Obese patients are at increased risk for hiatal hernia, which is one of the factors associated with DRGE ${ }^{7,28}$.

In this study, although there were hiatal hernia in all obese groups, it was not possible to correlate its presence with the progressive increase in BMI.

Moreover, while weight loss is often recommended as a therapy for improving reflux disease ${ }^{15}$, many studies are contradictory regarding its efficacy ${ }^{9,16}$. Small non-randomized studies suggest that weight loss after bariatric surgery may be associated with improvement of symptoms of reflux ${ }^{10,13}$, although none suggests that weight loss reduces the risk of esophageal adenocarcinoma. In this series, only were identified two patients with Barrett's esophagus, and no cases of esophageal adenocarcinoma.

Although positive association was identified between the presence of obesity and GERD, it would be expect that such association should be more significant, which may suggest another paradox of obesity ${ }^{24}$, mainly because GERD itself affects $6-22 \%$ of the occidental population ${ }^{19}$. However, highlights there are endoscopically diagnosed change, which features GERD as a significant comorbidity in the context of diseases associated with obesity.

\section{CONCLUSION}

There was a positive correlation between the degree of esophagitis with the BMI increase.

\section{REFERENCES}

1. Anderson MA, Gan SI, Fanelli RD, Baron TH, Banerjee S, Cash BD, Dominitz JA, Harrison ME, Ikenberry SO, Jagannath SB, Lichtenstein DR, Shen B, Lee KK, Van Guilder T, Stewart LE. Role of endoscopy in the bariatric surgery patient-ASGEASGESTANDARDSOFPRACTICE COMMITTEE. Gastrointest Endosc. 2008 Jul;68(1):1-10. Review.

2. Barak N, Ehrenpreis ED, Harrison JR, Sitrin MD. Gastro-oesophageal reflux disease in obesity: pathophysiological and therapeutic considerations. Obes Rev. 2002;3:9-15.

3. DeMeester SR, DeMeester TR. Columnar mucosa and intestinal metaplasia of the esophagus: fifty years of controversy. Ann Surg. 2000 Mar;231(3):303-21.

4. Devesa SS, Blot WJ, Fraumeni JF Jr. Changing patterns in the incidence of esophageal and gastric carcinoma in the United States. Cancer 1998; 83: 2049-2053
5. Di Francesco V, Baggio E, Mastromauro M, et al. Obesity and gastroesophageal acid reflux: physiopathological mechanisms and role of gastric bariatric surgery. Obes Surg 2004;14:1095-102.

6. El-Serag HB, Ergun GA, Pandolfino J, Fitzgerald S, Tran T, Kramer JR (2007) Obesity increases oesophageal acid exposure. Gut 56:749-755

7.El-Serag HB, Johanson JF. Risk factors forthe severity oferosiveesophagitis in Helicobacter pylori-negative patients with gastroesophageal reflux disease. Scand J Gastroenterol. 2002;37:899-904.

8. Fisichella PM, Patti MG. Gastroesophageal Reflux Disease and Morbid Obesity: Is There a Relation? World J Surg. 2009 Apr 29.

9. Fraser-Moodie CA, Norton B, Gornall C, Magnago S, WealeAR, Holmes GK. Weight loss has an independent beneficial effect on symptoms of gastro- oesophageal reflux in patients who are overweight. Scand J Gastroenterol. 1999; 34:337-40.

10. Frezza EE, Ikramuddin S, Gourash W, Rakitt T, Kingston A, Luketich J, et al. Symptomatic improvement in gastroesophageal reflux disease (GERD) follow- ing laparoscopic Roux-en-Y gastric bypass. Surg Endosc. 2002;16:1027-31.

11. Hampel H, Abraham NS, El-Serag HB. Meta-analysis: obesity and the risk for gastroesophageal reflux disease and its complications. Ann Intern Med 2005;143:199 211

12. Huang CS, Forse RA, Jacobson BC, et al. Endoscopic findings and their clinical correlations in patients with symptoms after gastric bypass surgery. Gastrointest. Endosc. 2003;58:859-66.

13. Jones KB Jr. Roux-en-Y gastric bypass: an effective antireflux procedure in the less than morbidly obese. Obes Surg. 1998;8:35-8.

14. Kahrilas PJ. The role of hiatus hernia in GERD. Yale J Biol Med. 1999;72: 101-11. [PMID: 10780571]

15. Kitchin LI, Castell DO. Rationale and efficacy of conservative therapy forgastroesophageal reflux disease. ArchIntern Med.1991;151:448-54.

16. Kjellin A, Ramel S, Rössner S, Thor K. Gastroesophageal reflux in obese patients is not reduced by weight reduction. Scand J Gastroenterol. 1996;31: 1047-51.

17. Lagergren J, Bergström R, Nyrén O. No relation between body mass and gastro-oesophageal reflux symptoms in a Swedish population based study. Gut. 2000;47:26-9.

18. MaddoxA, Horowitz M, Wishart J, Collins P. Gastric and oesophageal emptying in obesity. Scand J Gastroenterol. 1989;24:593-8.

19. Moraes-Filho JP, Chinzon D, Eisig JN, Hashimoto CL, Zaterka S. Prevalence of heartburn and gastroesophageal reflux disease in the urban Brazilian population. Arq Gastroenterol. 2005 AprJun;42(2):122-7. Epub 2005 Aug 24.

20. Murray L, Johnston B, Lane A, Harvey I, Donovan J, Nair P, et al. Relationship between body mass and gastro-oesophageal reflux symptoms: The Bristol Helicobacter Project. Int J Epidemiol. 2003;32:645-50.

21. Nandurkar S, Locke GR 3rd, Fett S, Zinsmeister AR, Cam- eron AJ, Talley NJ. Relationship between body mass index, diet, exercise and gastro-oesophageal reflux symptoms in a community. Aliment Pharmacol Ther 2004; 20: 497-505

22. Nilsson M, Johnsen R, Ye W, Hveem K, Lagergren J. Obesity and estrogen as risk factors for gastroesophageal reflux symptoms. JAMA. 2003;290:66-72

23. O'Brien TF Jr. Lower esophageal sphincter pressure (LESP) and esophagealfunctioninobesehumans.JClin Gastroenterol.1980;2:145-8.

24. Paula. Mcauley \& Stevenn. Blair . Obesity paradoxes, Journal of Sports Sciences, May 2011; 29(8): 773-782.

25. Shalauta MD, Saad R. Barrett's Esophagus. Am Fam Physician. 2004 May 1;69(9):2113-8. Review

26. Shaheen N, Provenzale D. The epidemiology of gastro- esophageal reflux disease. Am J Med Sci 2003; 326: 264-273

27. Wilson LJ, Ma W, Hirschowitz BI. Association of obesity with hiatal hernia and esophagitis. Am J Gastroenterol. 1999;94:2840-4.

28. Wu AH, Wan P, Bernstein L. A multiethnic population-based study of smoking, alcohol and body size and risk of adenocarcinomas of the stomach and esophagus (United States). Cancer Causes Control. 2001;12:721-32. 